\title{
Tietotekniikka ja aikuiskoulutus
}

Nykyisin puhutaan usein elämästä tietoyhteiskunnassa. Sen lisäksi elämme parhaillaan Pohjoismaiden neuvoston nimikoimaa Tekniikan vuotta 1988 (Data-Nordisk Datanytt 1/1988). Kielenhuoltajat ovat tosin kritisoineet vuoden suomenkielistä nimeä, sillä ruotsiksi vuosi on nimetty Nordisk Teknologiår 1988. Ongelma ei ole pelkästään kielellinen. Tekniikka merkitsee vain insinööritieteen tuottamia välineitä tehdä jotakin - teknologiaan sisältyvät sekä välineet että taito niiden käyttämiseen (Språkbruk 2/1987).

Tietoyhteiskuntakin on varsin pitkälti taitoyhteiskunta. Mitä tietoja, taitoja ja uusia arvoja hyvinvointivaltion kansalaiselta sitten edellytetään?

Kansalaiset voivat kohdata tietotekniikan sovellukset joko niiden käyttäjinä tai käytön kohteina. Näistä ehkä juuri tietotekniset sovellukset työpaikka- tai kotikäytössä tulevat ensinnä mieleen. Mainonta ruokkii tällaista käsitystä. On myös niin, että opetuksen, koulutuksen ja laajemmin "kansanvalistuksen" kannalta tietotekniikan koulutus on painottunut insinööritieteen näkökulmaan. Niinpä kursseja ja opastusta annetaan atk-laitteiden käytössä, ohjelmakäsikirjoissa ja tietokoneohjelmien eri versioiden ominaisuuksissa, laitetyyppien keskinäisessä vertailussa ja suorituskyvyssä jne. Vähemmälle huomiolle ovat jääneet tietotekniikan "sosiaaliset" vaikutukset.

Atk-laitteissa muodostuvan, tietotyöhön käytettävän työaseman arviointia suoritetaan myös työntekijän kannalta, ergonomiselta pohjalta. Esille tulevat vähitellen työsuojeluun ja työn ergonomiaan liittyvät asiat ${ }^{1}{ }^{1}$. Monet tietotyöläiset hankkivat atk-laitteistoja myös koteihinsa ja tällöin joudutaan harkitsemaan oikeudelliseltakin kannalta kielletyn ja sallitun välistä rajaa. On tällä hetkellä vielä epäselvää, saako työntekijä esim. käyttää työnantajaorganisaationsa ohjelmalisenssillä hankittua ohjelmatuotetta kotimikrossaan.

Lisääkin atk-ammattilaisten etiikkaan ja moraaliin sekä tavallistenkin työntekijöiden hyväksyttäviin käyttäytymismalleihin liittyviä asioita on helposti keksittävissä. Listaan niistä seuraavassa vain joitakin:

- Saako työpaikkaaa vaihtava atk-ammattilainen käyttää aiemman työnantajan tietämystä hyväkseen?

- Mikä on atk-alalla vallitseva hyvä käytän- tö tai rekisterinpitotapa?

- Saako ulkomaisia mikrotietokoneohjelmia käyttää ilmaiseksi omaksi hyväkseen, jos niitä saa tuttavalta käyttöönsä?

- Voiko tietopankkia käyttää ilmaiseksi tai sen tietoja muuttaa, mikäli sen tekniset suojaukset ovat puutteelliset?

- Kuka omistaa tietokantoihin kerätyt tiedot vai ovatko ne yhteisiä?

- Mitä tietopankkia käyttävä tai pankkikorttiasiakas voi tehdä hyväkseen, mikäli palvelu ei toimikaan?

- Milloin atk-laittein tuotettu atk-tallenne on luotettava asiakirjana tai teleliikenteessä välitettynä sopimuksena?

Osa yllä mainitsemistani ongelmista saattaa tuntua lakimiehen saivartelulta tai joka tapauksessa kaukaiseen tulevaisuuteen liittyviltä visioilta. Kuitenkin olemme jo nyt pitkälti kehittyneessä, verkottuneiden palvelujen yhteiskunnassa. Kehitys on lisäksi nopeata ja sitä tukevat viranomaistenkin toimenpiteet. Parhaillaan liikenneministeriö suunnittelee liikeyritystäkin tukien Minitel-mallin mukaan "kaiken kansan" atk-palveluja. Mukana ovat lisäksi julkiselta puolelta valtiovarainministeriö, opetusministeriö, posti- ja telelaitos, valtion tietokonekeskus, Ilmatieteen laitos, Kehitysaluerahasto sekä useita liikeyrityksiä.

Tele- ja atk-verkkoihin liittyy monia teknisiä, varsinkin järjestelmien yhteensopivuuden ongelmia. Samalla syntyvät monet oikeudelliset, lainsäädännöllä järjestettävät ongelmat. Lainsäädännön ja lainsäätäjän osa tietoyhteiskunnassa ei kuitenkaan ole helppo. Toisaalta normien tulisi olla tarpeeksi yleisiä kelvatakseen nopean kehityksen vauhtiin. Samalla niiden toisaalta tulisi olla riittävän teknisiä ja yksityiskohtaisia, jotta insinöörit ja atk-ammattilaiset saisivat niistä hyvät reunaehdot rakentuvalle infrastruktuurille. Kaikkea ei voi saada yhtaikaa ja jos jotakin saadaankin, on se auttamatta myöhässä ja syntyessäänkin jo vanhentunut.

Mistä tämä sitten johtuu? Lainsäädäntö syntyy monivaiheisen valmistelu- ja muokkausprosessin tuloksena. Yhteiskunnassa säädellään monia asioita, ei pelkästään tietotekniikan käyttöä. Lainsäädännön pohjana oli ennen syvällinen ja vakiintunut oikeusvakaumus: vankka käsitys oikeasta ja väärästä - sallitusta ja paheksutusta. Nykyisin lainsäädäntö perustuu 
edelleenkin moniin perusarvoihin, kuten inhimillisen elämän kunnioitukseen, mutta monesti se on luonteeltaan vain sosiaali-teknistä, välineellistä. Normien säätäminen edellyttää lisäksi säätämistarpeen määrittelyä (ratio legis), keinojen valintaa (esim. rangaistussäännökset) sekä lopulta normien luonnostelemista. Moraali ja etiikka kehittyy paljon hitaammin kuin tietotekninen infrastruktuuri. Kuka määrää tavoitetilan moniarvoisessa yhteiskunnassa?

Monimutkaisista asioista päättävät usein kapean sektoriasiantuntemuksen perusteella toimivat asiantuntijat. Liukuma asiantuntijavaltaiseen yhteiskuntaan on ilmeinen. Asiantuntijoina eivät julkishallinnossakaan ole enää pelkästään "byrokraatit", vaan lisäksi tuottavuusajattelun omaksuneet liike-elämän konsultit. Palvelujen tuottamiseen ja tietoteknisiin minimirutiineihin voi kuitenkin liittyä omia yksipuolisuuden aiheuttamia vaaratekijöitäkin. Julkishallinnon palvelukulttuurin luominen ei ole helppoa. Lisäksi jotkut laajat asiakokonaisuudet ovat niin monimutkaisia, etteivät niistä laaja-alaisesti päätä ketkään - kehitys vain kehittyy sitä kenenkään ohjaamatta. Jotakin olisi kuitenkin tehtävä. Aikuiskoulutus on uusien haasteiden edessä. Tietotekniikan tarjoamien palveluiden laadusta, tuottavuuden lisäyksestä ja sen jakautumisesta sekä yksilöllisestä luovuudesta olisi perusteellisesti keskusteltava. Tietoteknisen aikuiskoulutuksen järjestämistä on vaadittu myös kesäkuussa 1988 Suomessa järjestetyssä NordDATA 1988-konferenssissa.

Tilanne ei kuitenkaan ole yksinkertaisesti järjestettävissä. On pulaa asiantuntevista opettajista, mutta ei laitemyyjiin sidoksissa olevista konsulteista. On pulaa tietotekniikan yhteiskuntavaikutusta selvittävistä, puolueettomista "kansanpainoksista", mutta ei atk-laitteita ja tietokoneohjelmia kuvaavista julkaisuista. Atkalan kielenä on erään kynnyksen muodostava englanti. Lopuksi on pulaa myös yhteiskunnassa hyväksi havaituista käyttäytymismalleista ja eettisistä periaatteista.

Lakimiehiä on pitkään totuttu pitämään kehityksen jarrumiehinä, mutta myös laillisen yhteiskuntajärjestyksen tukipylväinä. Mitä lakimiehet ovat Suomessa osaltaan tehneet? Tähän ammattikuntaa kuuluvana haluaisin sanoa — paljonkin? Pitkän vuodesta 1971 saakka jatkuneen keskustelun ja poliittisen kiistelyn- kin tuloksena saatiin vihdoin keväällä 1987 säädetyksi henkilöstörekisterilaki, joka tuli voimaan kuluvana vuonna. Emme ole olleet tietoteknisen kehityksen ajopuu - monia säädöshankkeita mm. atk-rikollisuuden estämiseksi ja tietokoneohjelmien oikeudelliseksi suojaamiseksi on vireillä. Kritiikin aihettakin löytyy. Ensimmäisenä tulee esille lakimiesten oma ammatillinen perus- ja jatkokoulutus. Suomessa ei ole kolmessa oikeustieteellisessä tiedekunnassamme järjestettynä kuin oikeusinformatiikan alan peruskoulutusta. Kurssit eivät kuitenkaan korvaa tietoteknistä perustietämystä eivätkä luo kuvaa jo varsin pitkälle teknistyneestä yhteiskunnasta. Suomenkin olisi seurattava ulkomaisia opetusmalleja ja järjestettävä $\mathrm{mm}$. Euroopan neuvoston suosittelema oikeustietelijöiden perusopetus. Kansainvälistä kehitystä olisi seurattava vaikkakin kriittisesti. Tällöin eri ministeriöissä ja eduskunnassa vireillä olevat normihankkeetkin sujuisivat ehkä joutuisammin.

Edellä esittämääni taustaa vasten asettuvat julkisuudessa paheksutut "hakkeritkin" omaan asemaansa ja nykyisen yhteiskuntatilanteemme kuvaajiksi. Tietotekninen perustieto on yhteiskunnallisen edistyksen ja hyvinvoinnin edellytys. Lisäksi kaivataan välttämättä sekä poliittisen järjestelmämme ylläpitämiseksi että yksityisten kansalaisten ja asiakkaiden oikeuksien valvomiseksi laajaa koulutusta ja teknistyvän yhteiskunnan arvojen punnintaa. Vaihtuvatko pehmeät, perityt arvot laskennallisiin, rahamääräisiin suureisiin? Aikuisväestön monipuolinen tietotekniikkakoulutus osana aikuiskoulutusta $^{2)}$ on siis välttämätön, mutta varsin ylivoimaiselta vaikuttava tehtävä. Sitä eivät voi korvata pelkästään peruskoululaisten atk-opetus ja tietotupavisiot.

1) Vrt. myös työturvallisuuslain muutos (27 87), joka velvoittaa atk-laitteiden suunnittelijatkin ottamaan huomioon työaseman ergonomian.

2) Vrt. KM 1988:22 Aikuisväestön tietoteknisten valmiuksien parantaminen. 